\title{
The 1971 National Economic Plan
}

\author{
by KEITH M. CARLSON
}

$\mathrm{T}$ HE FEDERAL BUDGET, the Economic Report of the President, and the Annual Report of the Council of Economic Advisers were presented recently to Congress and the public. ${ }^{1}$ These three documents represent the Administrations national economic plan for the eighteen-month period ending June 30, 1972. Targets for total spending (GNP), output, prices, and unemployment are presented along with a proposed Federal budget program presumably consistent with these goals. Underlying the statement of targets and the Federal budget plan is an assumption regarding the course of monetary actions by the Federal Reserve System.

Specific targets for the U. S. economy are set forth by the Council of Economic Advisers (CEA) in their Annual Report.: These goals, stated with reference to second quarter 1972, consist of a reduction in the unemployment rate to near 4.5 per cent of the labor force and a reduction of the inflation rate, as measured by the GNP deflator, to near a 3 per cent annual rate. An 11 to 12 per cent amual rate of increase of total spending (nominal GNP) from fourth quarter 1970 to second quarter 1972 is proposed as a means of achieving these targets. To realize this advance of total spending, the CEA recommends an 8 per cent annual rate of increase in Federal expenditures and a continuation of the 5 to 6 per cent rate of monetary expansion which prevailed in 1970.

This article evaluates the Administration's national economic plan with the aid of a methodology developed at this Bank. The 1970 economic plan is compared with actual developments for purposes of obtaining some perspective on stabilization plams and realizations. Then, the 1971 economic plan is examined in terms of feasibility and internal consistency. The St. Louis model is used to evaluate the Administration's plan, thus any conclusions necessarily reflect the particular characteristics of that methotology.

The Budget of the United States Goternment, Fiscal Year Ending June 30, 1972 (Government Printing Office, 1971). and Economic Report of the President, together with The Ammal Report of the Conncil of Economic Adoisers (Go emment Printing Offce, 1971).

21971 CEA Repont, p. 78.

\section{Stabilization Actions and Economic Developments in 1970}

The recent Economic Report of the president described 1970 as a year of transition, when the U.S. economy paid for the excesses of 1966 through 1968. The general level of prices rose 5.3 per cent from fouth quarter 1969 to fourth quarter 1970 ,

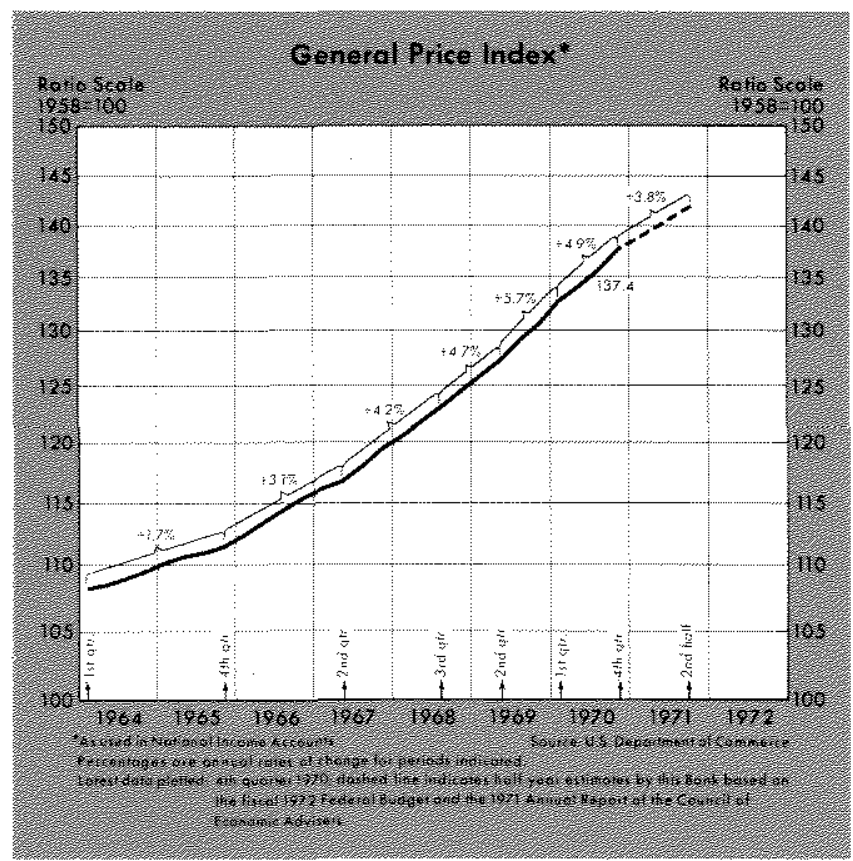

compared with a 5 per cent advance in the previous year, and unemployment rose from 3.6 per cent of the labor force in fourth quarter 1969 to 5.9 per cent a year later. Total spending increased at a moderate 4 per cent rate in the first half of the year, then stepped up to a 7 per cent rate in the second half (after allowance for the depressing influence of the auto strike in the fourth quarter ${ }^{.3}$ The faster advance of total spending in the second hall of the year was fostered by more rapid monetary expansion and increased growth of Federal spending beginning in arly 1970 .

\footnotetext{
The $\mathrm{CEA}$ estimated the impact of the fourth quarter strike to be approximately $\$ 14$ billion, or that total spending (GNP) would have risen at about a 7 per cent annual rate from third to fourth cuarter in the absence of the auto strike. See the 1971 CEA Report, pp. $34-36$
} 


\section{Fiscal Actons}

Federal budget actions were moderately stimulative in 1970, as Federal expenditures rose somewhat faster than during the previous year. Accelerated growth of Federal expenditures, along with expiration of the 10 per cent tax surcharge, resulted in a slight net fiscal stimulus during 1970 .

Expenditures - Federal spending in 1970 was dominated by developments in the second quarter. Effective in April, but retroactive to January 1, social security benefits were increased at a $\$ 4.3$ billion annual rate, and Federal employee compensation was raised at a $\$ 2.5$ billion anntal rate. The 7.1 per cent increase in Federal spending during the year ending fourth quarter 1970 compared with a 4.6 per cent rise during the previous year and a 13.4 per cent average ammal rate of increase from 1965 to 1968.

The advance of Federal spending from late 1969 to late 1970 reffected a 5.3 per cent decline in defense spending and a 16 per cent rise in nondefense spending. Defense spending had changed little in 1969, after increasing at a 15 per cent average annual rate from 1965 to 1968 . Nondefense spending

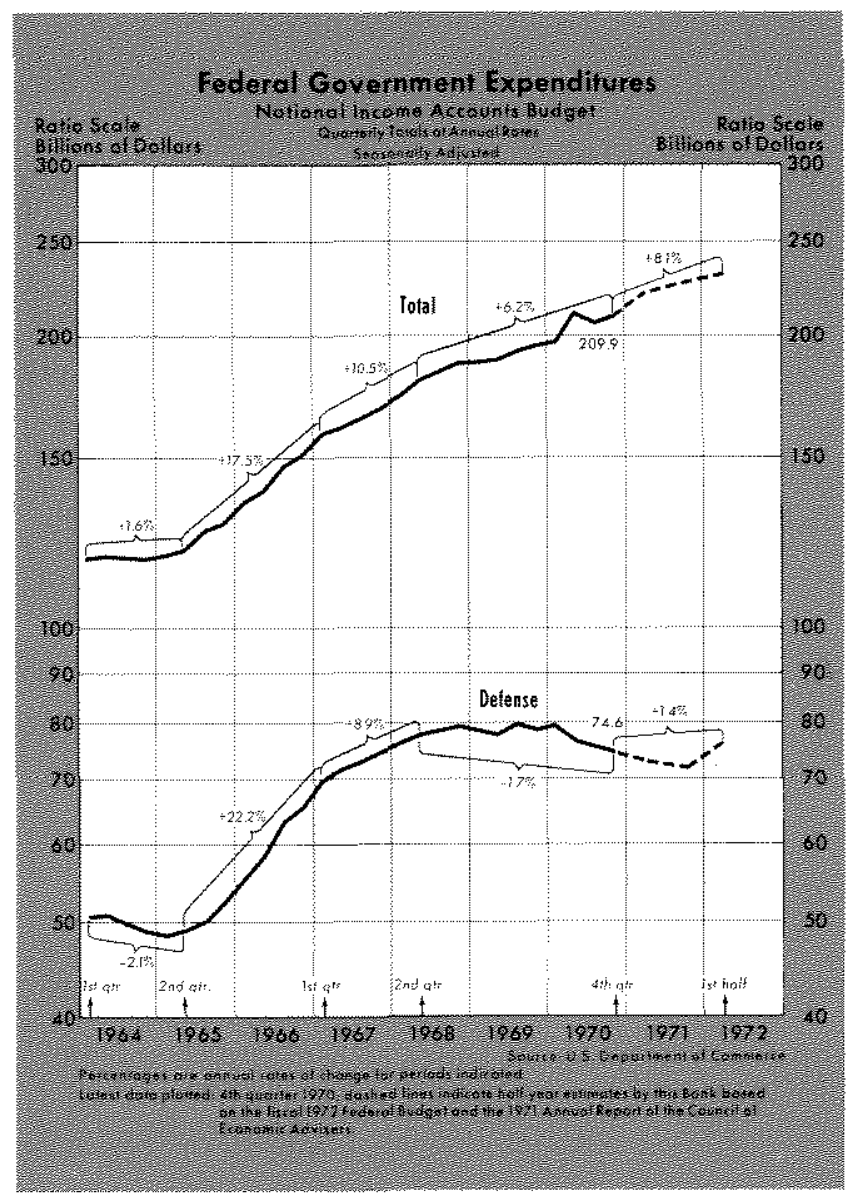

had advanced 8.4 per cent in 1969 following a 12.4 per cent average rate of increase from 1965 to 1968 .

Receipts - The major actions affecting budget revenues were the two-step elimination of the 10 per cent tax surcharge originally imposed July 1, 1968, and some net tax relief as a result of the Tax Reform Act of 1969. Expiration of the surcharge decreased Federal receipts by an estimated $\$ 8.3$ billion, This action, along with sluggish growth in economic activity, resulted in a $\$ 9$ billion dollar decline in Federal receipts from fourth quarter 1969 to fourth quarter 1970.

Surplus/deficit position - The combination of accelerated Federal spending. lower effective tax rates for personal and corporate income, and a reduced rate of advance of total spending in the economy, resulted in a shift of the national income accounts (NIA) budget from a $\$ 7.2$ billion annual rate of surplus in the second half of 1969 to a $\$ 14$ billion rate of deficit in the second half of 1970 .

The $\$ 21$ billion shift of budget position, as measured by the NIA budget, tends to overstate the extent of stimulus provided by the Federal budget. A substantial portion of the 1969 to 1970 shift from surplus to a deficit reflects the slowdown of the economy and is thereby misleading as a measure of discretionary fiscal action. Standardizing the estimates of expenditures and receipts on a high-employment basis provides a method of more accurately measuring the extent to which discretionary Federal budget actions were taken. On a high-employment basis, as estimated by this Bank, the NIA budget moved from a $\$ 10$ billion annual rate of surplus in the second half of 1969 to a $\$ 7$ billion rate in the second half of $1970 .{ }^{4}$ By comparison, this measure of the Federal budget averaged a $\$ 7.2$ billion rate of deficit from 1966 to 1968 .

\section{Monetary Actions}

Monetary actions in 1970 were quite expansive compared with the previous year, but according to most measures were less stimulative than in 1967 and 1968. The money stock increased 5.1 per cent during the year ending fourth quarter 1970, compared with 3.8 per cent in the previous year and a 7 per cent average rate of increase in 1967 and 1968.

\footnotetext{
*Estimates of the high-employment budget are prepared by this Bank and are published in our quarterly release, "Federal Budget Trends." These estimates differ slightly from those published in the 1971 CEA Report, pp. 24 and 73 . For further discussion of the high-employment budget concept, see the 1971 CEA Report, pp. 70-74.
} 


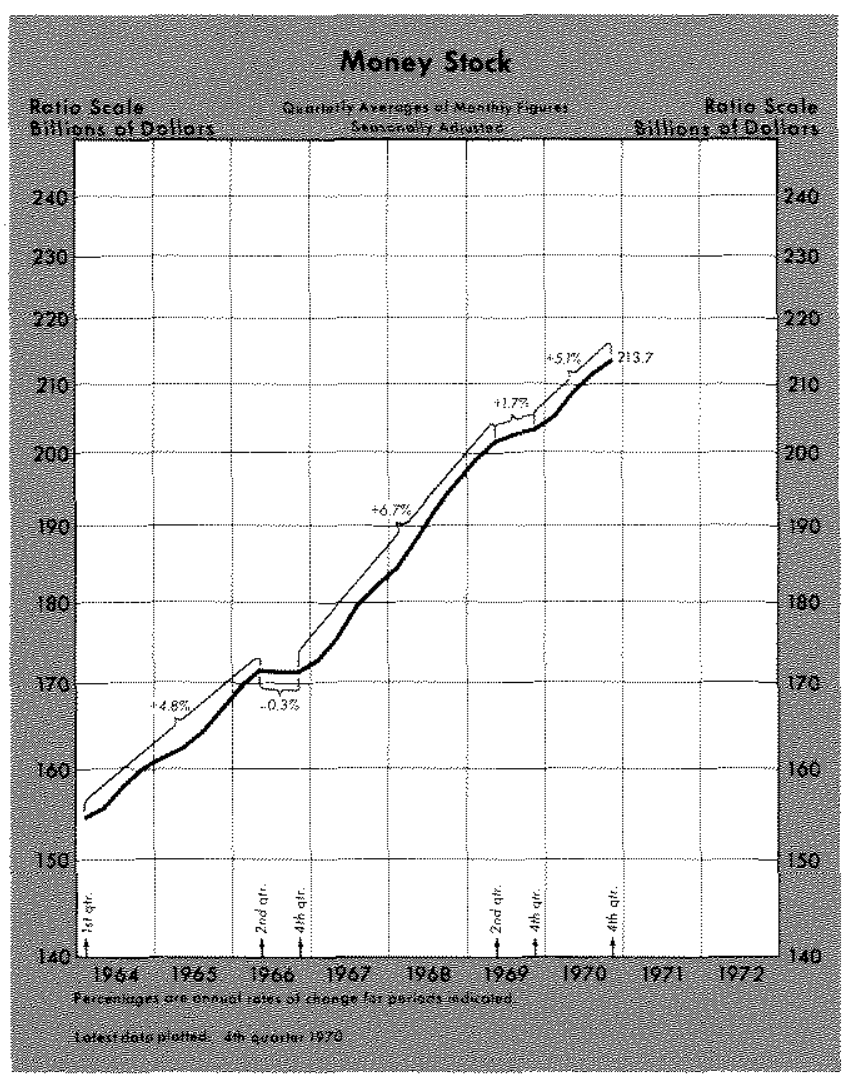

Evaluation of Last Year's Nutional Economic Plan

The CEA Report of a year ago projected a 5.7 per cent increase in total spending (GNP) for calendar 1970 over 1969. "The subsequent actual increase was 4.8 per cent, or, after adjusting for the effects of the auto strike in the fourth quarter, 5.2 per cent. The CEA anticipated a slow advance of total spending in the first half followed by a quickened pace in the second half. Apparently this pattern was realized, though an accurate assessment is clouded by the strike developments late in the year.

The CEA error of $\$ 7.6$ billion in projecting the growth of GNP from 1969 to 1970 was not large, considering that about $\$ 3.5$ billion was attributable to the auto strike. A comparison of the actual changes in the components of GNP with the CEA projections (Table I) indicates the primary source of error was overestimation of business fixed investment and of inventory accumulation. This type of forecasting error is common when the pace of economic activity is slowing; business investment plans typically are scaled back at such times. The other source of error, which partly offset the error in the investment projection,

1970 CEA Report, Chapter 2.

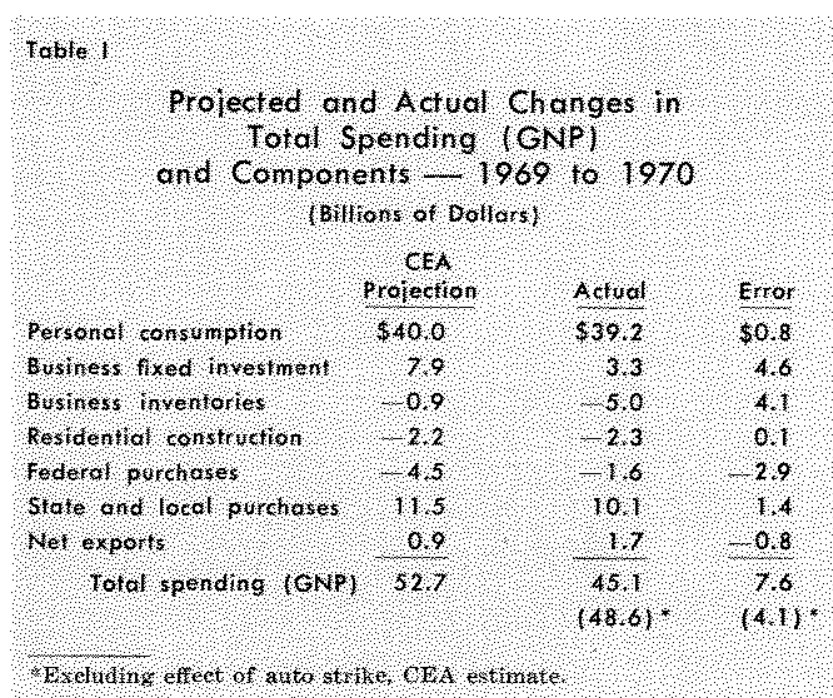

was underestimation of the growth of Federal purchases of goods and services.

Added relevance for stabilization policy is provided by the CEA projections of real product, prices and unemployment. Table II shows that the CEA projected an increase in real product from 1969 to 1970 of 1.2 per cent, a 4.4 per cent rise in the price level, and a rise in the unemployment rate of .8 per cent. Despite considerable success in projecting the growth in total spending, the CEA failed to anticipate the continued strength of inflation and the extent of sluggish growth in real product and employment.

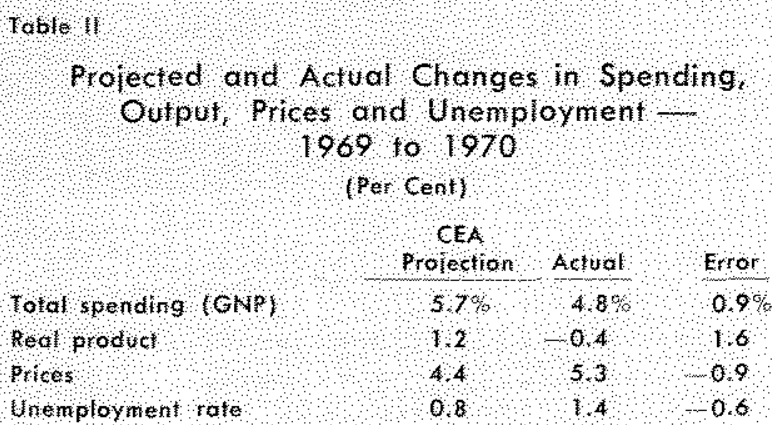

Stabilization plans vs. realizations - To evaluate the 1970 CEA projections and determine underlying sources of error, it is useful to compare monetary and fiscal plans with realizations. Table III gives planned and actual changes in the NIA budget from 1969 to 1970 on both an actual and a high-employment basis. From the standpoint of fiscal plans, the high-employment budget is more relevant. On this basis, expenditures increased $\$ 4.5$ billion more in 1970 than planned. Combined with a quite accurate projection of highemployment receipts, the change in net position 


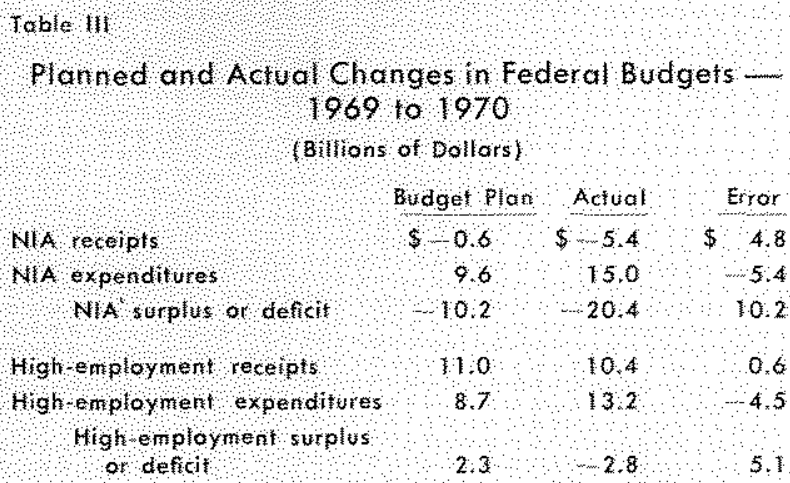

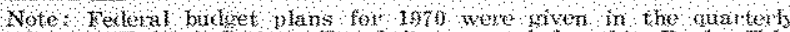

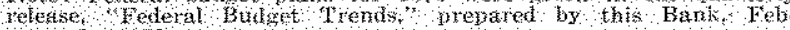
mat 30,100

turned out to be a slight stimulus compared with plans for sight restraint. This enor in fiscal planning is not luge, however, compared with some in the past.

The CEA assumption about monetary actions in 1970 was not specific in terms of a growth rate of the money stock, though a rate about mid-way between the 1967-68 rate and the rate in the second half of 1969 , or about 4.5 per cent, was implied." Money actally grew 5.1 per cent from fourth quarter 1969 to fourth quarter 1970. Consequently the CEA projection of monetary growth was quite accurate.

Analysis based on St. Louis model - To better understand the significmee of the diference between projected and actual changes in key economic variam bles from 1969 to 1970 , some alterna tive sinulations with the St. Louis methodology are examined. Four cases are considered: estimates based on (1) changes in money and expenditures as assumed by the CEA in February 1970 ; (2) perfect anticipation of changes in Federal expenditures, but not money; (3) perfect anticipation of changes in money, but not Federal expenditures; and (4) perfect anticipation of both money and expenditures.

Examination of Table IV suggests that the CEA was quite accurate in their total spending projection, mainly because they assumed an acceleration in the rate of monetary expansion in 1970. Federal expenditures advanced somewhat more rapidly than planned,

$\$ 1970$ CEA Report, p. 60.

i"A Monetarist Model for Ficonemic Stabilim zation," this Review (April 1970 ), pp. 7-25.

Table $y$ but this was not the primary source of eror, according to St Louis methodology, In tact, the propections based on policy assumptions were closer to the actual than were the projections based on perfect hnowledge about the course of these policy actions. Rabled monetary and fiscal actions implice that the projections should have been low rather than high. As a result based on the St Lous methodology, the CEA error in projecting total spending reflected factors other than errors in projecting the course of monetary and fiscal actions.

Though the CEA error in projecting total spending was not large, there were larger errors in projecting the division of total spending growth between prices and real product. Table IV shows prices, real product, and unemployment as profected and realized. Real product growth from alendax 1969 to 1970 was overestimated by the CEA, a projection of a 1.2 per cent increase, companed with no change in actual output (excluding the effect of the foum anarter strike). Unemployment was forecast to rise to a 4.3 per cent average for the year, but tumed out to be 4.9 per cent. The rate of inflation, on the other hand, was underestmated. The CEA in early 1970 expected a substantial improvement in price inflation over 1969 , projecting a 4.4 per cent increase. Prices actually rose 5.3 per cent from calendar 1969 to 1970.

Table IV shows that the projections for prices, output, and unemployment based on St. Louis methodology were more accurate than the CEA's protecPropected Changes in Spending, Oulput, Prices
and Unemployment - 1969 to 1970

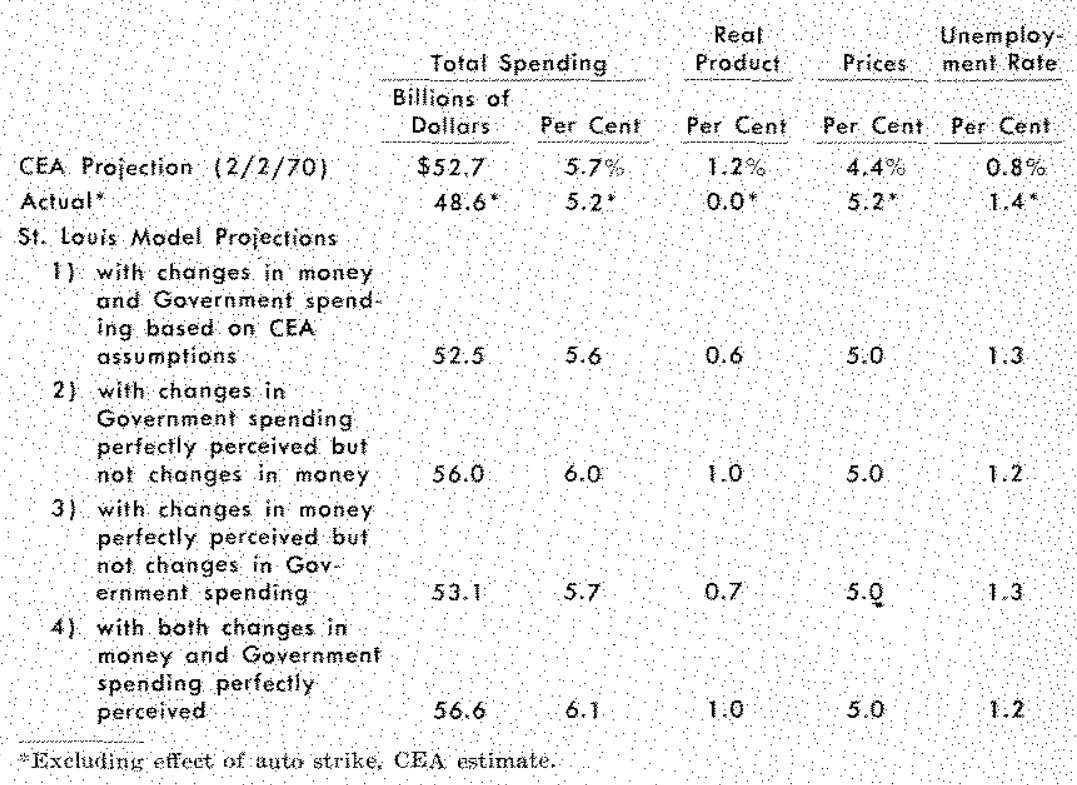


tions. Again, the St. Louis projections were more accurate when based on policy plans than when calculated with policy realizations. Nevertheless, despite the error in projecting total spending, the St. Louis methodology forecast prices to rise 5 per cent from 1969 to 1970 , or only slightly less than realized. Due to the slow short-run response of prices to monetary and fiscal actions in the St. Louis model, these price projections were relatively insensitive to the difference between policy plans and realizations.

St. Louis model projections of real product growth were in error by about the same amount as the CEA. By past projection experience, neither of the projections for real product, by the CEA or by the St. Louis methodology, were in substantial error. The differences between the projections by the CEA and St. Louis of real product translated into larger discrepancies in the projection of unemployment. The CEA correctly foresaw the rise in unemployment but underestimated its magnitude. The St. Louis model forecast the rise with considerable accuracy, even with a projection of real product growth similar to that by the CEA.

Summary - The CEA projected quite closely the growth of total spending, even though they underestimated the rise in Federal purchases from 1969 to 1970 by $\$ 3$ billion. Their errors were significant, how ever, with respect to projections of inffation and unemployment. The magnitude of these errors was typical of most forecasts, including those of large econometric models. As indicated in the 1971 CEA Annual Report, the inflation proved to be much more stubbom than anticipated. As a result, all of the advance in total spending manifested itself in price increases, and ontput did not grow at all, resulting in a much sharper rise in unemployment than anticipated. The St. Louis model, which has built into it a very slow price response, also underestimated the rate of inflation. For this one year, however, it came closer than the CEA in its projection of inflation and unemployment, despite the fact that the St. Louis model did not do as well in projecting the change in total spending:

\section{Economic Goals and Policy Plans for 197I}

The Administration has set targets of 4.5 per cent unemployment and a 3 per cent rate of inflation by second quarter 1972. To achieve these goals, a 9 per cent advance of total spending from calendar 1970 to 1971 has been projected. This section summarizes the Federal Budget program for calendar 1971., and then evaluates the Administration's plan with the aid of the St. Louis methodology.

\section{Fedenal Budget program for Calendar 1971}

The budget plan for calendar 1971 calls for a strplus in the high-employment (NIA) budget of $\$ 6.5$ billion, as estimated by this Bank. ${ }^{.}$A surplus of this magnitude would be about the same as in 1970 . When compared with calendar 1969 , the budget plan appears slightly more expansionary, but compared with the 1966 to 1968 period, when the high-employment budget was substantially in deficit, the budget for calendar 1971 appears much less expansionary.

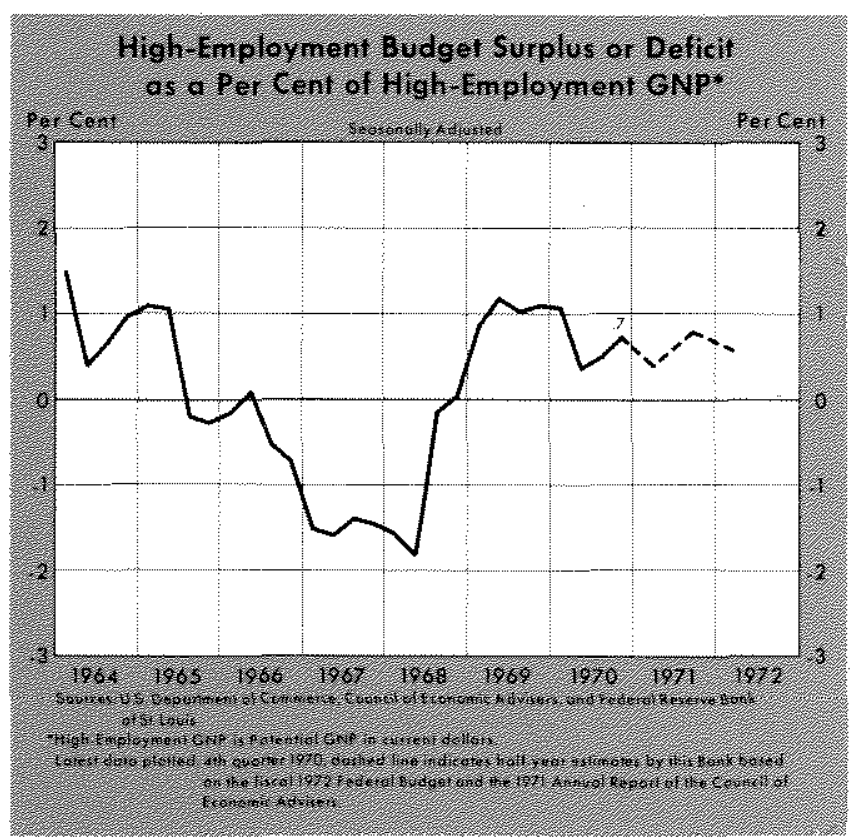

Expenditures - The budget plan projects an 8.4 per cent increase in Federal expenditures from calendar 1970 to calendar 1971. This increase would be up slightly from the 6.6 per cent rise in 1969 and 1970 , but much less than the 14 per cent average rate of advance in Federal spending from 1965 to 1968. The 1971 increase in Federal expenditures translates into about a 1 per cent advance in real terms, compared with a 1.3 per cent decrease in real terms in 1970 .

Defense spending is projected to decline about 5 per cent in calendar 1971 , compared with a 3 per cent decline in 1970 and a 1 per cent increase in 1969. The average annual rate of advance from 1965 to 1968 was a very rapid 16 per cent. Estimates for 1971 apparently reflect declines in Vietnam spending,

SThe Administration's budget progran is discussed as it relates to calendar 1971 rather than fiscal 1972 , with estimates for calendar 1971 prepared by this Bank. Furthernore, to be consistent with the GNP accourts, which represent the framework in which the CEA projections are made, the Federal sector of the rational income acounts (NIA budget), rather than the unified budget, is used to summarize Federal budget plans. For a summary of the budget program on a fiscal year basis, along with rate-of-change triangles, see the quarterly release of this Bank, "Federal Budget Trends," February 1971. 
though no figures are given in the budget as to their magnitude.

Federal spending on civilian programs, that is, nondefense spending, is planned to rise 16.5 per cent from calendar 1970 to 1971 . This increase would follow increases of 15 per cent in 1970 and 9 per cent in 1969. From 1965 to 1968 , nondefense spending rose at a 12 per cent average annual rate. 1971 expendiw tures for nondefense purposes reflect proposed increases in social security benefits and a pay raise for Federal employees, both effective January 1 , and ar increase in grants-in-aid to state and local governments (general revenue-sharing), effective October 1.

Receipts - Federal receipts on a national income accounts basis are projected to rise $\$ 18$ billion from calendar 1970 to 1971 , or by 9 per cent. This projection is closely associated with the assumption about the growth of total spending (GNP).

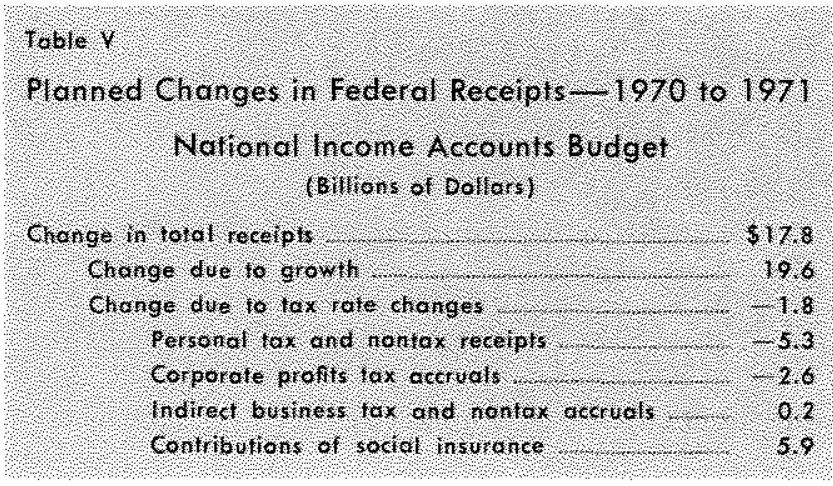

Table $V$ shows the sources of increased receipts for 1971. Changes in tax policy include (1) the scheduled increase in social security taxes, which was effective January $1,(2)$ a proposed expansion of the base for social security taxes, from $\$ 7,800$ to $\$ 9,000$, (3) continuing the effects of the Tax Reform Act of 1969 , and (4) the effect of liberalized depreciation allowances, tending to reduce receipts. The combined effect of these tax changes is expected to decrease receipts by $\$ 1.8$ billion in 1971. All of the expected increase in receipts reflects the rapid expansion of economic activity projected by the Administration.

Surplus/deficit position - The NIA budget is projected to be in deficit by $\$ 10.6$ billion in calendar 1971 , compared with a deficit of $\$ 11.1$ billion in 1970 . Since the NIA budget is influenced to a considerable extent by the pace of economic activity, it is useful to estimate receipts and expenditures on a high-employment basis. By elminating the effects of deviations in real economic activity from high-employment, budget plans can be assessed more accurately in terms of their economic impact.

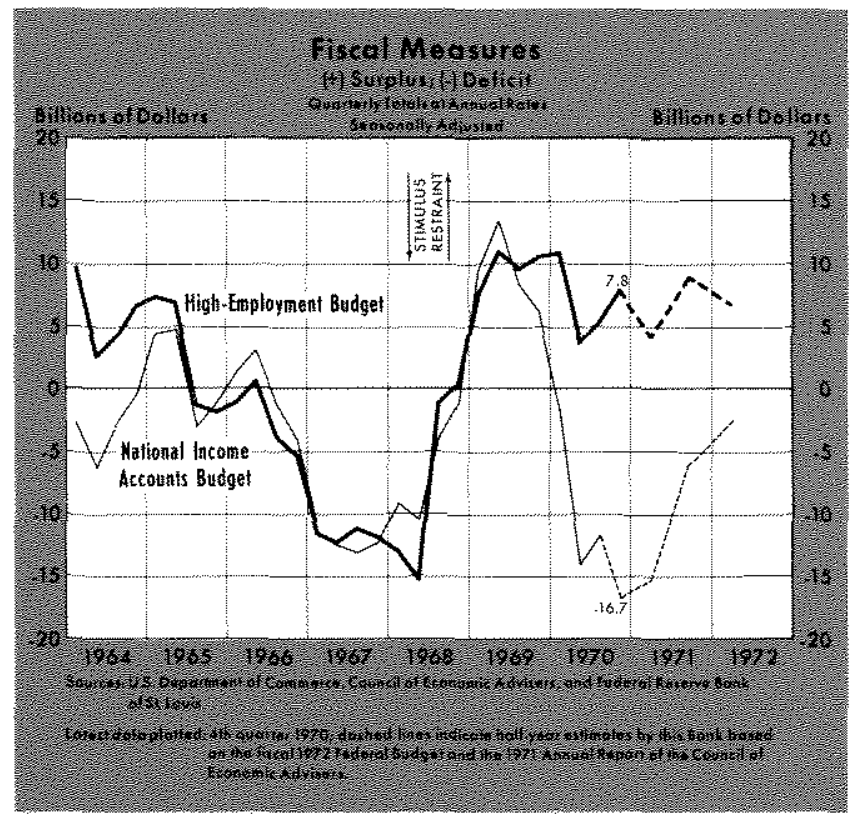

On a high-employment basis, the planned NIA budget indicates a $\$ 6.5$ billion surplus for calendar 1971. This estimate is about the same as for 1970 , indicating no change in the degree of fiscal stimulus from 1970 to 1971 .

The Federal budget program for calendar 1971 appears to contain about the same amount of stimulus as did the program in 1970 . Whether the impact of such a program will turn out to be essentially unchanged from 1970 depends largely upon Congressional action as well as the lag structure of economic reaction. Developments in Southeast Asia and domestic demands for Govermment programs are of vital importance in determining the actual course of Federal spending.

\section{Evaluation of 1971 National Economic Plan}

Using the St. Louis methodology, two questions are considered in the evaluation of the 1971 economic plan of the Administration: (1) whether the price and unemployment goals are consistent with the projected increase in total spending: and (2) whether the projected increase in total spending is consistent with proposed stabilization policies.

Feasibility of total spending goal - Table VI shows the results for the St. Louis model for four different combinations of policies:

(1) an increase of Federal spending as proposed in the budget and an expansion of the money stock at a 6 per cent annual rate; 


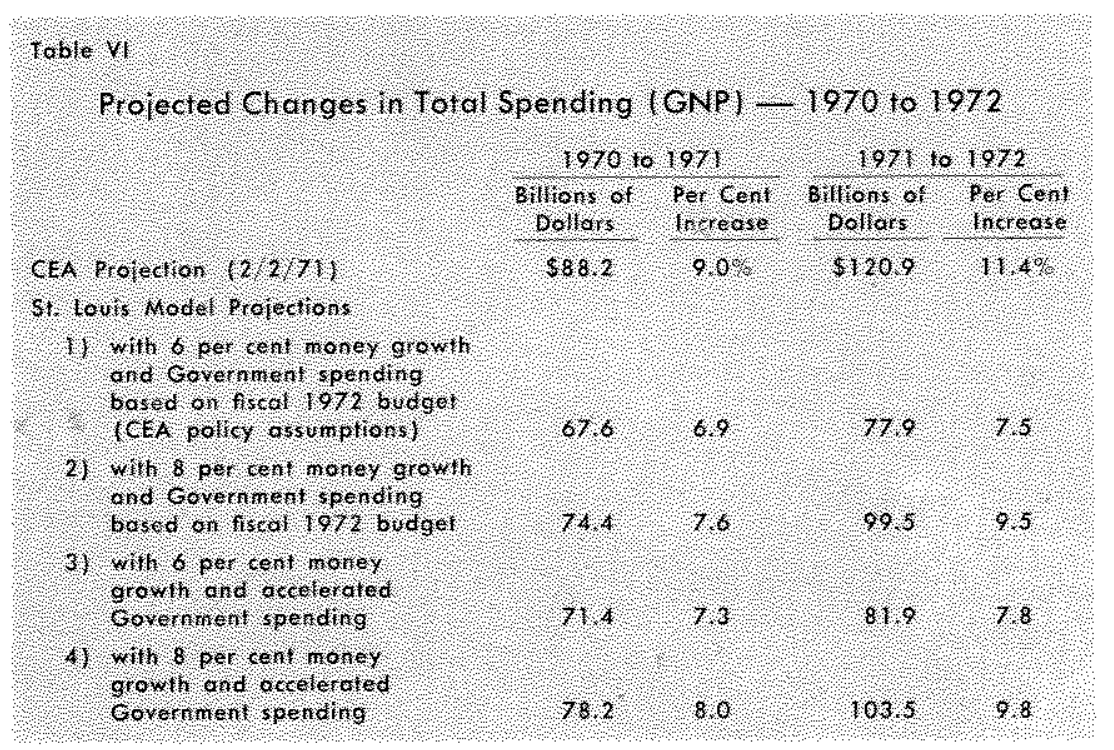

(2) an increase of Federal spending as proposed and a faster 8 per cent nate of expansion of the money stock;

(3) a faster increase of Federal spending than proposed and a 6 per cent rate of expansion of the money stock; and

(4) both a faster inclease of Federal spending than proposed and an 8 per cent rate of expansion of the money stock.

According to the St. Louis methodology (Table VT), the planned policies would not yield a growth in total spending of 9 per cent in 1971. Since the model is subject to error, the question arises whether this discrepancy is within the range of possible error. For this purpose, the model was used to forecast one year ahead, quarter by quarter from 1966 through 1970 . The largest error in prediction of total spending was $\$ 8$ billion, or substantially less than the $\$ 20$ billion discrepancy between the CEA projection and the St. Louts model projection based on their policy assumptions." The possibility of error in the St. Lovis model cannot be ruled out, but it seems most likely that continuation of monetary and fiscal stimulus in 1971 of roughly the same magnitude as we had in 1970 will not foster a sharp acceleration in growth of total spending in 1971. Because the monetary and fiscal restraint of 1968 and 1969 is fading into the past, total spending is projected to advance more rapidly in 1971 than in 1970, but not markedly so.

These forecasts were based on estimation of the total spending equation for a sample period thromgh 1966, then 1967, etc., and using actual money and expenditures to generate the forecasts outside of the sample period. Perhaps more relevant for the current situation is the performance of the model around business cycle turning points. Within the sample period of 1953 to 1970 , the average error for the fonrquarter period following business cycle troughs was $\$ 5.3$ billion, or 1 per cent of GNP in the four-quarter period ending with the trough fuater.
To determine if some other combination of policies might not yield the targeted growth of total spending, the impact of attemative policy assumptions was examined with the St. Louis methodology. Table VI suggests that the combination of more expansionary monetary and fiscal actions yields a total spending projection closer to the CEA's, but it still falls short by a substantial amount.

Implications of CEA total spending goal - The 1970 economic plan was in error primarily with respect to its distribution of total spending change between prices and real product. To assess the implications of the St. Louis methodology for real product, prices, and unemploy. ment, the CEA projections of total spending were assumed for the St. Lous model. Without concern for how the fotal spending is going to be achieved, Table VII shows the implied paths for real product, prices, and unemployment. ${ }^{\text {th }}$

According to these estimates based on the St. Louis model, real product would rise about 4 per cent from calendar 1970 to calendar 1971, compared with the CEA projection of 4.6 per cent. As a result, the St. Louis model suggests unemployment would average 5.5 per cent in calendar 1971 , or slightly above the CEA projection of 5.3 per cent. Furthemore, the St. Louis model indicates that the CEA projection of total spending would lead to a 4.9 per cent advance of prices in 1971, compared with the CEA estimate of 4.2 per cent.

The difference between the CEA projections and those based on the St. Louis methodology becomes more evident when examined with reference to 1972 . The CEA projections imply that real product would continue its strong advance in 1972 , rising 7.7 per cent above 1971, and pash the unemployment rate down to a 4.4 per cent average for the year. The St. Lous model also indicates a rapid increase of real product, but at a slower 6 per cent rate of advance. Unemployment would be redueed for 1972 to 5.1 per cent of the labor force. In shap contrast with the CEA projection of a 3.4 per cent increase in prices in 1972 , the $S$. Louis model shows a 5.2 per cent increase.

\footnotetext{
10Given the proposed Federal budget program, the $\mathrm{St}$. Louis model indicates that a 12 per cent rate of increase in money beginning in first quarter 1971 would be required to achieve the CEA projection of a 9 per cent increase in GNP in calendar 1971 .
} 
Toble $\mathrm{vl}$

Projected Changes in spending, Output, Prices and Unemployment 1970 ro 1972

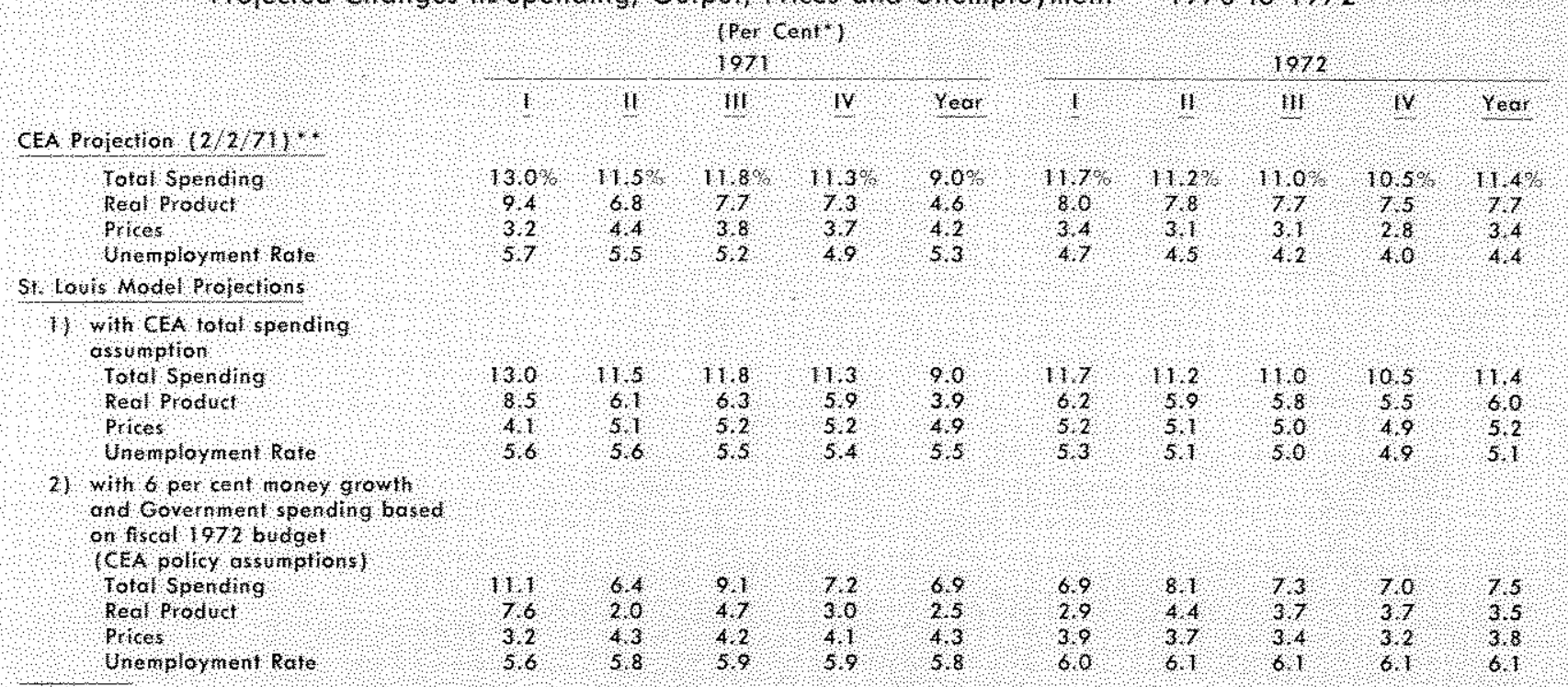

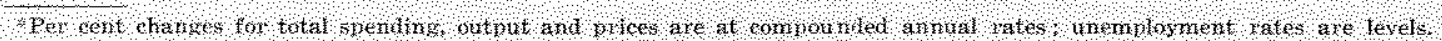

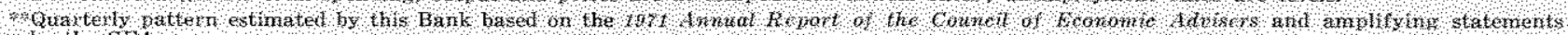
by the

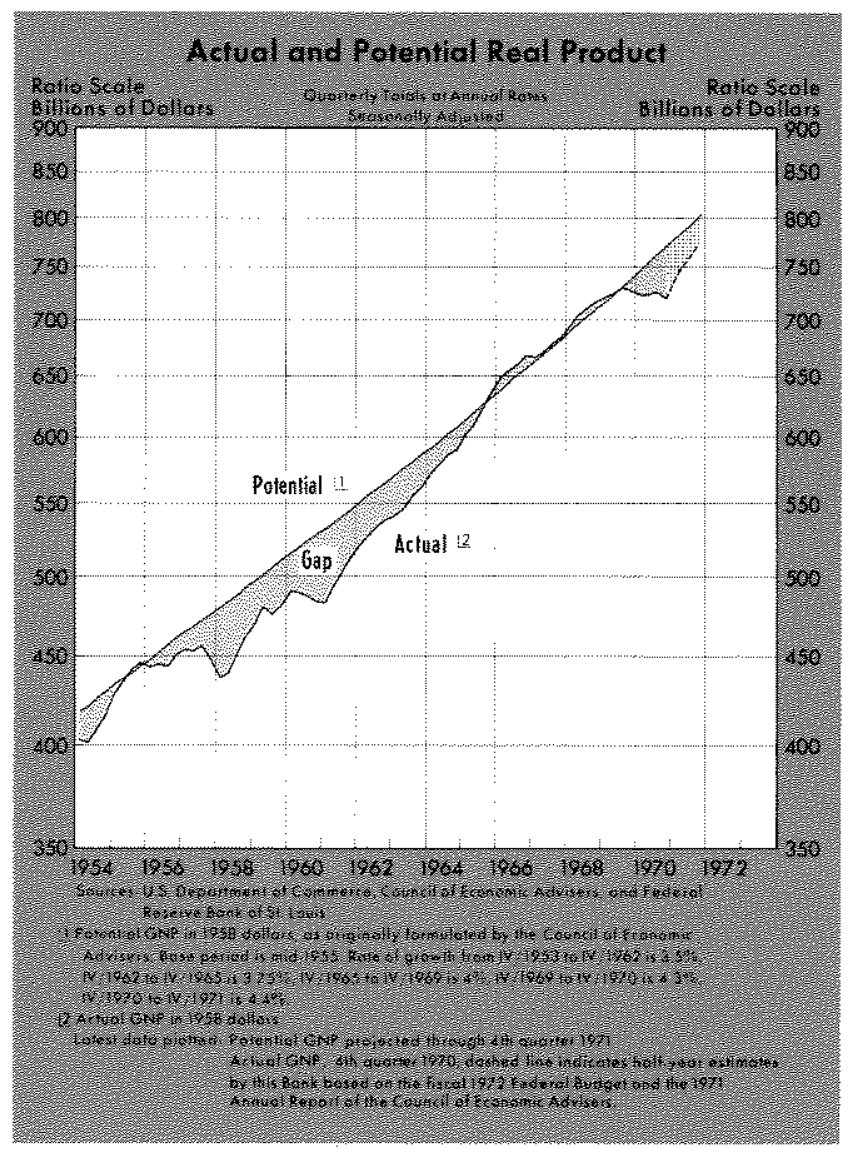

In summary, introtucing the CEA projection of total spending into the St. Louis model leads to the conclezsion that such a policy of rapid spending growth would provide stight gains in reducing unemployment. However, such gains would be at the cost of no gains in the battle against infation.

\section{Summary}

The Administration has forecast that the U. S. economy in 1971 will attain reductions of memployment and inflation simultaneously. To achieve these goals, a rapid expansion of total spending has been proposed. According to methodology developed at this Bank, the projected increase in total spending is not consistent with the policy actions proposed by the Administration. A much slower increase is more likely.

Furthermore, when the targeted increase of total spending is accepted (which is only possible in the St. Louis model with a very rapid acceleration of monetary and/or fiscal stimulus), the goals for unemployment and prices also appear too optimistic. Our model suggests that such a policy of rapid spending growth would lower memployment, but inflation would continue unabated.

The nation is faced with a serious dilemma, but a search for quick and easy solutions may be selldefeating. The current inflation developed persistently over a substantial period of time. For this reason the current problem defies a fast and smooth adjustment to high employment with price stability. Monetary actions consisting of a 5 to 6 per cent annual rate of growth in money, and fiscal actions consisting of an 8 per cent amnual rate of advance in Federal expenditures, appear to be consistent with an orderly, but slow, return to a viable high-employment path. The post World War II economic experience does not indicate that the present unemployment-inflation dilemma can be solved as quickly as the CEA has suggested.

An Appendix to this article is on the next page. 


\section{APPENDIX}

\section{ALTERNATIVE BUDGET CONCEPTS}

All references to the Federal budget in the preceding article are in terms of the national income accounts budget. "This appendix discusses three budget concepts to provide the reader with an understanding of their interrelations.

\section{Unified Budget}

The unified budget was adopted as the Govermment's basic planning doctment in January 1968, replacing both the administrative and consolidated cash budgets. Expenditures and receipts are recorded on a cash basis (when the checks are issued or the payment received). This budget will be presented on an accrual basis after accounting procedures are revised. Net transactions of trust funds are included in this budget. All lending activities of the Govermment as well. as certain Government. sponsored agencies are described in the unfied budget, but only certain direct loans are included in the figures for total outlays (expenditures plus net lending). (For a complete discussion of Federal lending activities see "Special Analysis $\mathrm{E}$ " in Special Analyses: Budget of the U. S. Covernment, Fiscal Year 1972).

The unified budget is presented to Congress for approval by the President in January or February of every year, for the fiscal year ending June 30 , eighteen months hence. Also included are revised figures for the current fiscal year ending approximately six months later. The Offce of Management and Budget nomally revises the budget figures for the coming fiscal years in the spring and fall of every year. The current data are published by the Treasury Department on a monthly basis.

\section{National Income Acconnts Rudget}

The national income accounts (NIA) budget presents the receipts and expenditures of the Fedenal Government as ar integrated part of the economy, as represented by the national income and product accounts. The major differences between the NA budget and the omified budget are: (1) the NIA budget excludes all lending transactions; (2) tax receipts in the NIA budget ate, in general, recorded on an accrual basis (corporate income taxes are accmed when the income is eamed rather than when the Govemment receives payment, and personal income taxes, most of which are witheld from eamings or paid on a quarterly basis, are recorded when the taxpayer makes payment); (3) on the expenditure side. defense purchases are recorded when the items are received by the Covernment wher than when they are produced or paid for.

The NA butget is developed in conjunction with the rest of the national income accounts by the Department of Commerce. It is published on a quarterly basis, seasonally adjusted at annual rates. "Special Analysis $A$ " in the fiscal 1972 budget contains a more detailed description of the reconciliation of the unifed budget with the NIA budget.)

\section{High-Employment Budget}

The high-employment budget is based on the NIA budget; however, it is adjusted to remove the effects of the level of economic activity on the NIA budget. For example, during a recession NIA receipts will tend to fall in response to lower levels of income, and NIA expenditures for unemployment benefits will rise. The restalting move toward deficit in the NIA budget, however, implies expansionary policies when, in fact, the opposite might be occurring

The high-mploynent budget reflects primarly discretionary changes in fiscal policy, such as a change in the tax rate structure or a change in the patten of expenditures. The high-employment budget estimates published by this Bank are based on potential gross national product as defined by the Council of Economic Advisers. In their 1970 Annual Report, the CEA defined potential GNP as the output of the econorry at a 3.8 per cent memployment rate. Incone shares and tax rates, estimated at high-employment levels, are applied to potential GNP in current dollars to arive at the high-employment budget data. Such data are not published regularly by any Government agency. Estimates prepared by this Bank are published in the quarterly release, "Federal Budget Trends." 


\section{ER R A T A}

The gray-screened portion of the following table was incorrect as published on page 18 of the March 1971 issue of this Review, The outlined portion of the table shows the correct figures (with the incorrect figures, as originally published, in parentheses). All other figures in the table were correct, and are reproduced below. The conclusions of the article, though not altered fundamentally, were modified in the direction of making the difference between the CEA projection and the St. Louis model projection, based on the CEA total spending assumption, slightly less pronounced than indicated in the article. We thank Frank C. Ripley, Senior Staff Economist, Council of Economic Advisers, for pointing out this error.

Table VII

PROJECTED CHANGES IN SPENDING, OUTPUT, PRICES AND UNEMPLOYMENT - 1970 to 1972 (Per Cent*)

\begin{tabular}{|c|c|c|c|c|c|c|c|c|c|c|}
\hline $\begin{array}{l}\text { CEA Projection } \\
(2 / 2 / 71)^{* *}\end{array}$ & 1 & 11 & 111 & IV & Year & 1 & 11 & III & IV & Year \\
\hline Total Spending & $13.0 \%$ & $11.5 \%$ & $11.8 \%$ & $11.3 \%$ & $9.0 \%$ & $11.7 \%$ & $11.2 \%$ & $11.0 \%$ & $10.5 \%$ & $11.4 \%$ \\
\hline Real Product & 9.4 & 6.8 & 7.7 & 7.3 & 4.6 & 8.0 & 7.8 & 7.7 & 7.5 & 7.7 \\
\hline Prices & 3.2 & 4.4 & 3.8 & 3.7 & 4.2 & 3.4 & 3.1 & 3.1 & 2.8 & 3.4 \\
\hline $\begin{array}{l}\text { Unemployment } \\
\text { Rate }\end{array}$ & 5.7 & 5.5 & 5.2 & 4.9 & 5.3 & 4.7 & 4.5 & 4.2 & 4.0 & 4.4 \\
\hline
\end{tabular}

S1. Lovis Model Projections

1) with CEA total

spending assumption

$\begin{array}{lllllllllll}\text { Reat product } & \end{array}$

prices

Unemployment

Rate

2) with 6 per cent

money growth and

Government spend-

ing based on fiscal

1972 budget (CEA

policy assumptions)

\begin{tabular}{|c|c|c|c|c|c|c|c|c|c|c|}
\hline Total Spending & 11.1 & 6.4 & 9.1 & 7.2 & 6.9 & 6.9 & 8.1 & 7.3 & 7.0 & 7.5 \\
\hline Real Product & 7.6 & 2.0 & 4.7 & 3.0 & 2.5 & 2.9 & 4,4 & 3.7 & 3.7 & 3.5 \\
\hline Prices & 3.2 & 4.3 & 4.2 & 4.1 & 4.3 & 3.9 & 3.7 & 3.4 & 3.2 & 3.8 \\
\hline $\begin{array}{l}\text { Unemployment } \\
\text { Rate }\end{array}$ & 5.6 & 5.8 & 5.9 & 5.9 & 5.8 & 6.0 & 6.1 & 6.1 & 6.1 & 6.1 \\
\hline
\end{tabular}

* Per cent changes for total spending, output and prices are at compounded annual rates; unemployment rates are levels.

$\therefore$ Quarterly pattern estimated by this Bank based on the 197 Annal $n$ eport of the Courcil of Fconomic Advisers and amplifying statements by the CEA. 